Барабаш О.В., кандидат фоілособських наук, доцент, докторант

Харківського національного педагогічного університету імені Г. С. Сковороди

ORCID ID: 0000-0001-8479-8926

\title{
РІЗНОРІДНІСТЬ ПОЛІТИЧНИХ ПРОЦЕСІВ У ЛАТИНСЬКІЙ АМЕРИЦІ Й КАРИБСЬКОМУ БАСЕЙНІ ТА ТРУДНОЩІ ПЕРСПЕКТИВИ «СТАЛОГО РОЗВИТКУ»
}

\begin{abstract}
Анотація. У статті поставлена і частково розглянута проблема можливості «сталого розвитку» у дусі положень спеціальної програми ООН у країнах Латинської Америки та Карибського Басейну за умов нинішніх складнощів економічного характеру, викликів соціально-політичного характеру і за наявності проблем як власне місцевого гатунку, так і загальносвітового характеру. Здійснена спроба з'ясувати, на якому змістовному підгрунті та за яких сприятливих факторів і цілеспрямованих дій завдання програми будуть успішно результативними. Виявлено, що країни Латинської Америки та Карибського Басейну (ЛАКБ) після періоду поступового проникнення й закріплення окремих інститутів демократичного політичного режиму і передусім саме у зв'язку з упровадженням демократичного електорального законодавства (що на певний час знизило як фактичну кількість, так і ймовірність державних переворотів з подальшим зламом політичної системи) вступили у фазу демократичної рецесії, поширення стратегій позаінституційного протистояння політичних акторів, поновлення вуличних протестних технологій у політичному процесі (Венесуела, Болівія, частково і секторально Чилі, Перу, Колумбія). Тому захист завоювань демократії в регіоні розглядається в контексті необхідності консолідованого відстоювання демократії в світі й зменшення ризиків для ії майбутнього існування. Підкреслено, що на фоні проблем розвитку світової економіки та переорієнтації щодо політекономічних стратегій на національному рівні змістовний центр щодо бачення перспектив зміщується від бінарності «демократія - тоталітаризм» до змістовної площини, яка пов'язана з факторами економічного зростання та соціальною захищеністю. Економічний складник сучасних світових, у тому числі політичних процесів, визначається одним 3 ключових. Підсумовано, що багато в чому подальший розвиток подій і в світі, і в регіоні, в тому числі щодо варіації рішення комплексу проблем соціальної якості у співвідношенні з баченням економічного зростання, буде залежати від парадигми розвитку, що буде визначена в найближчі рік-два у США. Підкреслено значення розробки програм-стратегій національного розвитку на рівні окремих країн та впровадження інноваційних технологій.

Ключові слова: Латинська Америка і Карибський Басейн, демократична рецесія, сталий розвиток, політичні процеси, соціальна нерівність, геополітика.
\end{abstract}

Вступ. Вочевидь, сучасний світ увійшов у фазу переформатування багатьох системних параметрів щодо співіснування держав, суспільств, економік, об'єднань різного гатунку, оди- ничних суб'єктів (у тому числі новітнього характеру), з перспективами невизначеності проблематики розвитку, непередбачуваності ризиків майбутності, що будуть актуалізуватися у процесі спонтанності плину «текучої сучасності» і за умов турбулентності змін. Латинська Америка і Карибський Басейн (ЛАКБ) завжди були одним 3 найчутливіших щодо тенденційності й змістовної показовості регіоном відносно «загальної симптоматики» трансформаційних спрямувань як локального, так і загальносвітового значення, а 2019 рік виглядає загалом знаковим на фоні, по-перше, спроб віднаходження алгоритмів геополітичної поведінки основних «гравців» усіх рівнів політики в ситуації намагань ствердження конфігурацій багатополярності з визначенням кола домінантних інтересів, больових порогів, червоних ліній максимізації ризиків, по-друге, зі ствердженням у світі різноспрямованих політекономічних стратегій внаслідок зміни курсу однієї з ключових економік світу - неолібералізму формату гегемонії на «національний розвиток» у США часів президентства Д. Трампа i, зрештою, по-третє, завершення великого регіонального виборчого циклу на рівні країн у зв'язку з плановою компанією виборів Президента Аргентинської Республіки. Додатково змістовним і неоднозначним виглядають контексти місцевих політичних процесів з урахуванням того стратегічного бачення перспектив людства, що було сформульовано й трансформовано в конкретику векторів-завдань у Резолюції, що прийнята Генеральною Асамблеєю ООН 25 вересня 2015 року, - «Перетворення нашого світу: Порядок денний у сфері сталого розвитку до 2030 року». Цей документ демонструє глибинність усвідомлення масштабності й загрозливості сучасних викликів - у підрозділі «Наш світ сьогодні» констатується: «14. Ми зустрічаємося у час, коли на шляху сталого розвитку постали величезні виклики. Мільярди наших громадян досі бідують, позбавлені можливості жити гідним життям. Посилюється нерівність усередині країн та між ними. Наявні колосальні диспропорції у розподілі можливостей, матеріальних цінностей та влади...» [1]

Постановка проблеми. За умов нинішніх складнощів економічного характеру, викликів соціально-політичного характеру і за наявності проблем як власне місцевого гатунку, так i загальносвітового характеру чи $є$ можливим «сталий розвиток» у дусі положень спеціальної програми ООН в країнах (ЛАКБ), на якому змістовному підгрунті і які фактори здатні сприяти комплексному вирішенню завдань розвитку та результативно успішним перетворенням? 
Мета і завдання роботи. Мета роботи - з'ясувати окремі чинники й тенденції політичних процесів у регіоні та інші фактори впливу на розвиток країн ЛАКБ, вийти на розуміння можливостей і рекомендацій щодо реалізації програмних положень ООН відносно ствердження «сталого розвитку». Завдання - проаналізувати окремі фактори і явища політичного життя, виділити складнощі розвитку, центри зосередження змістовних напружень, позначити вплив геополітичних аспектів на загальну ситуацію, визначити варіації заданості у політичному процесі запитів суспільства щодо рішення блоку питань соціального характеру та налаштованість ключових акторів щодо визначення політ-економічної стратегії розвитку у контекстах загальносвітової боротьби за економічне зростання і водночас соціальну захищеність.

Аналіз останніх досліджень і публікацій. Серед вітчизняних авторів, що досліджують окремі аспекти проблематики, відзначимо роботи В.Ю. Карасьова, що займається аналізом і подальшою концептуалізацією явищ геополітичного характеру, політекономічних стратегій сучасності, у тому числі стосовно процесів у ЛАКБ. Характер і сутність сучасних конфліктів у контекстах кризи лібералізму, розвитку політичних режимів з виходом на регіональну проблематику розробляють І.Д. Денисенко, І.О. Поліщук, Г.М. Куц. Тематикою моделювання мережевих політичних процесів, підходів і методологічних напрацювань займається М.А. Польовий. Стосовно політичних процесів системного характеру в регіоні виділимо роботи О.І. Ткача, особливо відносно заходів застосування м'якої сили. Серед зарубіжних авторів щодо предметної площини нашого дослідження аналітичний моніторинг і аналіз ситуації в країнах ЛАКБ проводять Б. Геддес, Л. Даймонд, Д. Зіблатт, С. Левицький, З.В. Івановський, Т.О. Воротнікова, Ю.М. Саямов, Н.М. Яковлева, П.П. Яковлев, Д.В. Морозов та інші.

Виклад основного матеріалу дослідження й отриманих результатів. Формування нової світової економічної парадигми на фоні спрямування курсу найрозвиненіших національних економік на якісно відмінний технологічний уклад зі змінами параметрів галузевого гатунку, залученням сучасних науково-інформаційних надбань і похідним зростанням факторів природно-ресурсного забезпечення перетворює регіональний латералізм неоліберальних часів президентства Б. Обами на тенденцію формування інтеграційних мегаблоків, що поступово задають нові умови та правила міжнародної торгівлі. Власне, економічні інтереси закладають і лінії представлення геополітичних трендів сучасності - у світовій політиці прагматизм інтересів витісняе романтизм ідеологій. У цьому смислі ЛАКБ як регіон, що зосереджує значну частку земних ресурсів, $\epsilon$ ареною боротьби за успішність в реалізації своїх економічних задумів та водночас «місцем створення проблем і демонстрації можливостей щодо деструктивну» по відношенню до конкурентів. Політичні процеси в регіоні тією або іншою мірою $\epsilon$ пов'язаними як з реалізацією геополітичних стратегій власне країн-представників регіону, так і з присутністю задумів, намірів, дій США, Китаю, Росії. Китай останнім часом діє в регіоні через підключення країн ЛАКБ до реалізації свої економічних намірів, проводячи системну роботу з міністрами - представниками країн напряму та в режимі швидкої взаємодії у межах і двосторонніх зв'язків, і багатостороннього формату в рамках Азійсько-Тихоокеанського економічного співробітництва
(АТЕС). Привабливість взаємодіїз Китаєм зумовлюється насамперед значним обсягом інвестицій Китаю і сумарним потенціалом його економічних можливостей. США, що тривалий час «запрошували прикладом» до взаємодії в період неоліберальної гегемонії і виступали у ролі «плеча демократії», більшою або меншою мірою ще з часів ствердження «доктрини Монро», водночас розглядали регіон в контексті зв'язків з власними економічними інтересами, а щодо питань безпеки, у тому числі економічної, адміністрація Б. Обами реалізовувала проект двох океанських кіл - тихоокеанського і атлантичного. Могутня економіка США і приваблива можливість взаємодії $з$ нею, важелі ïx фінансового, дипломатичного впливу, залишать США головним і бажаним для частки місцевих еліт гравцем у регіоні. Тривалий час розбудовував свою стратегічну взаємодію в регіоні СРСР, яка базувалась на ідеологічному підгрунті та фінансових можливостях щодо підтримки дружніх країн - ці напрацювання геополітичного характеру вже поза чітко вираженим ідеологічним аспектом використовує сьогодні Росія, і такі стосунки мають свою привабливість і ефективність щодо реалізації національних інтересів (нещодавно Росія знову списала борги африканським країнам на загальну суму 20 млрд дол., тоді як одній тільки Кубі - більш ніж 31 млрд дол.). Інтереси держав перетиналися в багатій нафтою Венесуелі, у якій окремі нафтові свердловини і права на розробку інших належать Російським компаніям, нафтопереробні потужності «важкої» венесуельської нафти знаходяться переважно у США, а головним іiі споживачем є Китай. Затяжна криза у Венесуелі зрештою дозволила зберегти владу дружньому Росії президенту Н. Мадуро. Втім, регіональне лідерство Венесуели і життєвість проекту ALBA під iї супроводом було поставлено під сумнів, а зі зміною лідера в Еквадорі і орієнтацією Леніна Морено на співпрацю з США та відсторонення від участі в ALBA цей регіональний блок опинився під загрозою розпаду. Після відвідин Н. Мадуро Москви, зустрічі з В.В. Путіним та переоріснтації в регіоні Гватемали на співпрацю з Євразійським Союзом розпочалась серія бурхливих протестних подій, пов'язаних 3 підвищенням цін на громадський транспорт саме в Еквадорі, а також в країні - «вітрині лібералізму», надійного союзника США з могутніми ВМС - Чилі. Слідом за тим ми споглядали, як внаслідок вуличних акцій опозиції було зміщено президента Болівії Ево Моралеса - одного з найбільш послідовних прибічників політики В.В. Путіна. Болівія загалом знову стає центром світового економічного інтересу у зв'язку з наявністю родовищ літія, необхідного для виробництва акумуляторів для електромобілів (Болівія вважається «батьківщиною глобалізації», оскільки саме в ній зі срібла, що здобувалась в горі Потосу, склались передумови щодо появи першої світової валюти (срібний долар), яка поєднувала економічну діяльність в усьому світі впродовж 3 століть). I зрештою протестні акції в Колумбiї, країні, що тривалий час зорієнтована на співпрацю з США і чиї потужні сухопутні збройні сили є головною загрозою для Венесуели. Таким в загальних рисах $€$ геополітичний підтекст в комплексі взаємопов'язаних політичних та соціально-економічних процесів у регіоні зі своєю внутрішньою і зовні не очевидною логікою.

Поряд зі ствердженням поширеної тези, що Латинська Америка $€$ певним полігоном для запровадження і відпрацювання нових, експериментальних за сутністю технологій політичного та економічного характеру, на нашу думку, має право 
і міркування, що саме в цьому регіоні найбільш виразно, соціально-амплітудно проявляються риси актуалізації проблемності майбутнього, окреслюються тенденції загальносвітових змін. Так, навіть за умов змістовної волатильності [2], результативної поляризації та високого ступеня непередбачуваності усіх складників політичного процесу (про що свідчать хід і дані політико-виборчої кампанії в регіоні), великого циклу, який «підсумували» вибори Президента Аргентинської Республіки, i загалом усі поточні політичні події можна виділити puntos clave de concentración del significado de la perspectiva (ключові пункти зосередження щодо позначування перспективи).

1. Країни Латинської Америки та Карибського Басейну (ЛАКБ) після періоду поступового проникнення й закріплення окремих інститутів демократичного політичного режиму і передусім саме у зв'язку зі впровадженням демократичного електорального законодавства (що на певний час знизило як фактичну кількість, так і ймовірність державних переворотів 3 подальшим зламом політичної системи) вступили у фазу демократичної рецесії, поширення стратегій позаінституційного протистояння політичних акторів, поновлення вуличних протестних технологій у політичному процесі (Венесуела, Болівія, частково і секторально - Чилі, Перу, Колумбія). Тому захист завоювань демократії в регіоні розглядається в контексті необхідності консолідованого відстоювання демократії в світі й зменшення ризиків для іiі майбутнього існування [3]. Загалом ситуація, за даними опитування Latinobarometro 2018 та 23 щорічної конференції [4], індикативна, виражена i симптоматична, зокрема відзначається почуття втоми від демократії, задоволеність демократією знизилась 3 44\% до $24 \%$ населення регіону, є широко представленими громадянський спротив та гнів по відношенню до політики й політичної еліти, рівень легітимності політичних партій і законодавчих органів оцінюється, відповідно, на рівні 13\% та 21\%. Токсична комбінація настроїв і факторів в регіоні зрештою робить достатньо високою вірогідність конфронтаційних сценаріїв розвитку й веде до зниження порогів соціально-прийнятного в політичних процесах у напряму прийняття насилля як складника політичної боротьби. До 40\% представників регіону готові підтримати недемократичні режими, що здатні забезпечити гідний матеріальний рівень життя. Тільки Коста-Ріка та Уругвай зрештою визнаються повними демократіями і не викликають стурбованості щодо розвитку подій у цих країнах.

Загально-регіональна проблема - корупція. У Гватемалі президентом Джеймсом Ернесто Моралесом Кабрера, який має передати свої повноваження новообраному президенту Алехандро Едуардо Джаматею Фалла вже в січні 2020 року, припинено діяльність міжнародної організації CICIG [5] (Comisión Internacional contra la Impunidad en Guatemala - Міжнародна організація проти безкарності в Гватемалі), що понад десятиріччя боролась у цій країні з корупцією, і це певною мірою виглядає капітуляцією перед проблемою, «яка в Латинській Америці має системний та всеосяжний характер» $[6$, с. 12]. Загалом багато в чому підтверджуються висновки і передбачення щодо сутності політичних процесів в регіоні Н.М Яковлевою: «Латинська Америка вкотре знаходиться на порозі системної кризи керованості й політичної нестабільності з причин низької якості регіональних еліт та сумнівної репутації інституту президентства. Це відкриває додаткові можливості для представників політичної альтернативи й позасистемних акторів у трансцен- дентному електоральному циклі 2018-2019 рр., передбачити результати якого не уявляється можливим» [7, с. 180]. Дійсно, актуальним для регіону стало і новітне лідерство, як за формами його прояву, так і відносно змісту діяльності. Є суспільний запит на незвичні постаті в політичному процесі. Певний час найпопулярнішими лідерами в світі за показниками своєї внутрішньої підтримки залишались президенти Андрес Мануель Лопес Обрадор (Мексика) та обраний на самому початку 2019 року Наїб Армандо Букеде Ортес (Сальвадор), які якісно опанували можливості спілкування з використанням новітніх інформтехнологій, медіа засобів. Рівень їх підтримки тривалий час знаходився на високій позначці $71 \%$. Наїб Букеле під час виборів використовував ролики-звертання через Twitter, а зараз вже привчив країну до своїх публічних розпоряджень й наказів через соціальні мережі [8]. Щодо появи на політичній арені позасистемних політиків - шоумена, коміка та кінопродюсера Джимі Моралеса в Гватемалі та інших, ми вже аналізували ситуацію [9].

За новітніми форматами і медіазасобами простежується й змістовність процесів. Венесуела як носій ліворадикальної ідеології «соціалізму XXI століття» переживає затяжну кризу сама ідея виглядає в регіоні вже не настільки привабливою. За переважно правоцентристською ідеологією лідерів більшості країн регіону (Жаїр Мессіас Болсонару - Бразилія, Мігель Хуан Себастьян Піньєра Еченіке - Чилі) залишається простір і для лівоцентристської позиції (Андрес Мануель Лопес Обрадор Мексика та, скажімо, Карлос Альварадо Кесада - Коста-Ріка), бо спільний знаменник дерадикалізації та зближення позицій площина соціальних завдань, необхідність подолання одних i тих же проблем: бідність, злочинність, корупція, безробіття, забруднення навколишнього середовища.

2. На фоні проблем розвитку світової економіки та переорієнтації щодо політекономічних стратегій на національному рівні загалом змістовний центр щодо бачення перспектив зміщується від бінарності «демократія - тоталітаризм» до змістовної площини, яка пов'язана 3 факторами економічного зростання та соціальною захищеністю. Економічний складник сучасних світових, у тому числі політичних процесів визначається одним $з$ ключових. The world today seems almost suddenly awash in change. Economies struggle everywhere, the Middle East is in flames, and national borders seem to mean less than ever before [10, с. 18]. За концептуалізації у США нинішнього стратегічного політико-економічного курсу як Nation Developmentalism [11, с. 169] та запереченням неоліберального розвитку часів президентства Барака Обами, з подальшим виходом на боротьбу ще 4 стратегій, серед яких є представленим навіть демократичний соціалізм Берні Сандерса, країни ЛАКБ демонструють варіації своєї стратегічної зорієнтованості і мають вирішувати дилему економічного зростання, що представляється: або узагальнений статистичний матеріал 3 покращеними показниками (Жаїр Болсонару - лідер Бразилії - слідує за курсом США i стилем Дональда Трампа), або і за вимірів достатньої соціальної захищеності (Андрес Мануель Лопес Обрадор у Мексиці заявив про омани лібералізму та впроваджує широкі соціальні програми щодо підвищення якості освіти, безоплатності іï та медицини тощо [12]). Якщо ж запускається достатньо радикальний лівий за змістом сценарій перерозподілу соціальних благ (Венесуела, Нікарагуа, Болівія [13]), що порушує системні параметри ведення бізнесу за ліберальними стандартами, 
проглядається відтік капіталу, зниження показників розвитку й подальші проблеми економічного характеру. Після поразки президента Маурісіо Макрі на виборах в Аргентині, з обранням лівих поглядів лідера Альберто Анхеля Фернандеса майже відразу обвалилась місцева грошова одиниця - аргентинський песо, очікуються кризові явища в колись одній з найсильніших економік регіону, що вже тривалий час (особливо з початку XXI ст.) переживає важкі часи. Втім, і слідування стратегії лібералізму, або популярній за часів ще до Рональда Рейгана радикальній версії індивідуалізму з практичним виходом держави 3 площини надання й забезпечення соціальних гарантій по відношенню до громадян - лібертаріанству - сповнене ризиками несвоєчасності та результативної програшності на фоні того ж національного розвитку. Як відзначає представник академічних кіл Лондона Алекс Каллінікас: «Парадокс навіть не в тому, що неолібералізм у кризі, а в тому, що це й до сьогодні офіційна доктрина економічної політики у більшості країн» [14].

Загалом на фоні програм боротьби з бідністю та соціальною нерівністю, що впроваджуються на рівні ООН, досліджень капіталізму ст. Тома Пікетті $з$ аналітикою щодо виявлення основ соціальної нерівності та представлення заходів іiі подолання [15], оприлюднення результатів наукового пошуку лауреатів Нобелівської премії 2019 Абхіджита Вінаяка Банерджі та Естер Дюфло, які займались рандомізованими польовими дослідженнями щодо дієвих засобів боротьби з бідністю (Їх висновок: найбільш ефективні 3 них - якісна освіта та медицина), проблема алгоритму співіснування економіки зростання й інститутів соціального захисту набуває значення однієї $з$ ключових.

Відносно формування соціальної нерівності в доповіді Т. Пікетті відзначається тенденція зростання показників нерівності в усьому світі й значимість у цьому процесі політичного контексту: «Динаміка нерівності в доходах прямо залежить від того, яку траєкторію розвитку вибирали держави. Колишні і нинішні комуністичні країни 3 високою часткою держрегулювання (Китай, Росія, Індія), що мають обмежену «відкритість світу», зіткнулися з особливо різким зростанням нерівності» [15]. Індекс Джині, який відтворює загальну картину щодо представлення нерівності в світі по країнах, у матеріалах стосовно 2018 року відносить і більшість країн ЛАКБ до тієї частину списку, де соціальна нерівність за показниками цього індексу виражена найсильніше - 7. Колумбія $(48,90)$, 8. Гондурас $(48,30), 12$. Панама $(46,10), 13$. Чилі $(45,90)$, 14. Мексика $(45,90), 15$. Коста-Ріка $(45,70), 17$. Перу $(45,40)$, 18. Бразилія $(44,90), 19$. Парагвай $(44,90), 21$. Домініканська Республіка $(44,60), 22$. Гватемала $(44,50), 26$. Болівія $(43,50)$, 27. Нікарагуа $(43,20), 43$. Сальвадор $(38,90), 46$. Аргентина $(38,60), 54$. Уругвай $(37,00)$. (Для порівняння - 4. Китай $(51,00)$, 24. Російська Федерація $(43,90), 49$. США $(37,80), 87$. Франція $(29,90), 89$. Швейцарія $(29,30), 91$. Німеччина $(29,00), 98$. Україна $(26,30), 106$. Норвегія $(24,90)$.) [16]. Звичайно, як будь-які показники, що базуються на статистичних даних, мають свою ступінь погрішності і надають певну лінійність результативному підсумку, але водночас вони і дозволяють виокремити контурності змістовного характеру. Країни, що потрапляють у високу частину індексу Джині, мають бути готовими до можливих проявів форм соціального незадоволення, спроб трансформацій політичної системи, або щонайменше політичних процесів «поза зоною звичайності». В цьому ракурсі поточні події в Чилі, Колумбії, Еквадорі, Болівії також проявляють риси певної тенденційності.

Як свідчать місця в індексі Джині, насамперед країн Північної Європи, демократичний політичний режим $і$ його заходи щодо соціальної захищеності населення, створення механізмів перерозподілу соціальних благ та загалом цілеспрямована політична робота дають суспільно-прийнятний результат відносно подолання нерівності. Один з ключових висновків, що робить Т. Пікетті у своєму дослідженні, - тенденція концентрації багатств зберігається, (маркери іiі особливого посилення: 1980-ті рр. та після світової економічної кризи 2007-2008рр.) i скоріше за все наблизиться до того рівня, що існував перед початком Першої світової війни - його критичність стала однією з причин запуску механізмів перерозподілу «початку довгого періоду руйнації багатств, експропріації та росту оподаткування...» [15].

Окрім кореляцій політичного розвитку як засобу запобігання зростання нерівності пропонуються також такі заходи подальшого убезпечення від нерівності: прогресивне оподаткування, яке знижує нерівність не тільки після самого факту сплати вищих податків, а й обмежує найбагатших людей від подальшого підвищення своєї зарплати і майнового накопичення, та знову ж таки - «рівний доступ до освіти і до високооплачуваних робочих місць» [15]. Певним підтекстом щодо сучасних аналітичних матеріалів навколо кризи неолібералізму виглядає проблема кризи сучасного капіталізму загалом, з багатьма параметрами різного гатунку, серед яких в соціально значимих контекстах виділяється комплекс питань захищеності різних верств людей, сучасного «прекаріату» 3 варіаціями конкретизації обов'язковості представленості соціального інтересу, у тому числі завдяки встановленню поособових виплат, що не залежать від участі у виробничих процесах і за умов сучасних технологій виробництва 3 їх підсумковою результативною надлишковістю мають гарантувати гідний спосіб життя будьякій людині. Наукове опрацювання подібних сценаріїв подальшого розвитку свідчить про те, що поряд з очікуванням катастрофізму майбутності в науці моделюються й оптимістичні варіанти розвитку, які мають своє підгрунтя, а їх можливість пов' язується в тому числі з кардинальними змінами системних параметрів капіталізму і з форматуванням нових перерозподільних механізмів. «Сучасний капіталізм все одно працює не дуже добре > ..> зберігається невідрефлексована неоліберальна політика в структурах, де здійснюється влада...» [14].

Багато в чому подальший розвиток подій і в світі, і в регіоні, в тому числі щодо варіації рішення комплексу проблем соціальної якості у співвідношенні з концептуальним баченням економічного зростання, буде залежати від тісї парадигми розвитку, що буде визначена в найближчі рік-два у США у взаємозв'язку і з виборчою кампанією Президента США, проте і з загальною зорієнтованістю по відношенню до майбутності усього американського істеблішменту. Можливо у цьому відіграє свою роль й рефлексія 3 приводу питання, яке акцентовано актуалізує Алекс Каллінікас: «Цікаве питання - це не чому Трамп виграв, а чому Клінтон програла. Вона працювала до цього 20-30 років, у неї у якості попередника був популярний президент. I тут причина в тому, як мало політичний й економічний істеблішмент робить задля рішення масштабних проблем» [14]. Зрештою, про що свідчать передвиборчі програми і Елізабет Воррен і Берні Сандерса, у США також 
проробляються різні шляхи рішень викликів новітнього характеру, що вже яскраво проявились в ЛАКБ - формування на фоні сучасних загальносвітових кризових явищ стратегій розвитку з урахуванням глобальних завдань в руслі концепції «стійкого розвитку» $\mathrm{OOH}$ з необхідністю ствердження перерозподільних програм, реалізацією соціальних проектів і заходів вдосконалення капіталізму, що, за А. Каллінікасом, може стати початком зрушень системного характеру: «Чудово, якщо Сандерс переможе, але це буде кошмар, як тільки він потрапить до Білого дому. Автори американської конституції не були дурнями: вони передбачили такий дизайн системи, щоб не дати народній більшості запустити перерозподільні програми» [14].

Висновки і перспективи подальших досліджень. На наш погляд, найближчим часом регіон в цілому та окремі його країни очікують політично-амплітудні і за змістом, і за характером події, що відносно таких понять, як стабільність і спрямованість розвитку, мають перспективи, що складно визначити в конкретиці цифр і прогнозів - настільки велика сума параметрів різного гатунку впливає на перебіг подій. Зрештою, маємо люфт 3 великим оцінним зазором. На фоні зниження показників економічного зростання, що є одними з найсуттєвіших за останні роки у світі, перетину інтересів найвпливовіших геополітичних гравців і корупції, яка має загально-регіональний характер, навіть такі потужні країни, як Бразилія та Мексика, не позбавлені ризиків політичної турбулентності та настання фаз різнорідної протестності, спрямованої на руйнацію системних основ політичних систем, держустрою, що може призвести до непередбачуваних результатів (ситуація в Венесуелі, падіння економіки Аргентини, «капітуляція» перед корупцією в Гватемалі та інше - тому приклади), простежуються і певні загрози розвитку демократії в регіоні. На наш погляд, відносно формування майбутнього вирішальними можуть стати 2 позиції: 1. «Битва за контроль над світовою економікою у 21 ст. буде виграна і програна через контроль над інноваційними технологіями» [17]. Серед країн регіону Чилі та Мексика мають найвищі 58 та 59 місця у рейтингуванні інноваційних економік, що означає, що якщо ситуація не зміниться на краще, країни будуть залишатися осторонь прийняття стратегічних рішень, на периферії економічного прогресу і у ситуації відсутності ресурсів щодо реалізації соціальних програм. 2. «78. Ми рекомендуємо всім державам-членам якомога скоріше розробити національні програми з амбітними цілями... Вони можуть підтримувати перехід до досягнення цілей сталого розвитку і базуватись на наявних інструментах планування, таких як стратегії національного розвитку...» [1]. Розробка програм національного розвитку із залученням спеціалістів-практиків, науковців, бачиться нам одним 3 найважливіших ресурсів національного і водночас сталого i успішного розвитку. Подальший розвиток ситуації в регіоні 3 аналізом факторів впливу на політичні процеси і соціальні заходи окреслює площину подальших досліджень.

\section{Jimepamypa:}

1. Резолюція «Перетворення нашого світу: Порядок денний у сфері сталого розвитку до 2030 року» (2015). URL: http://sdg.org.ua/ua/ resources-2/344-2030-2015.

2. Winners Never Quit, Quitters Never Grow: Using Text Mining to Measure Policy Volatility and Its Link with Long-Term Growth in Latin America*. URL: https://openknowledge.worldbank.org/bitstream/ handle/10986/29220/WPS8310.pdf?sequence=1\&isAllowed=y.
3. A Century Of Ideas: Battleground Of Perception: Countering Threats To Free And Open Societies Tuesday, June 4, 2019. Hauck Auditorium, Stanford University. URL: https://www.hoover.org/events/ century-ideas-battleground-perception-countering-threats-free-andopen-societies.

4. The 23rd Annual Conference of the Development Bank of Latin America WASHINGTON, D.C., USA PUBLISHED: 12/09/2019. URL: https://www.idea.int/news-media/news/23rd-annual-conferencedevelopment-bank-latin-america.

5. Guatemala's anti-corruption CICIG body to shut down: What to know. As CICIG's mandate comes to an end this week, here's why the anti-corruption body mattered and what happens next. by Sandra Cuffe 1 Sept 2019 [Електронний pecypc]. URL: https://www. aljazeera.com/news/2019/08/guatemala-anti-corruption-cicig-bodyshut-190830225625800.html.

6. Ивановский 3.В. Коррупция как системный фактор. Латинская Америка. 2017. № 2. С. 12-35.

7. Яковлева Н.М. Латинская Америка: президентская власть и оппозиция в XXI веке. Контуры глобальных трансформаций: политика, экономика, право. 2018. Т. 11. № 3. С. 166-184.

8. URL: https://twitter.com/nayibbukele.

9. Барабаш О.В. Окремі штрихи трансформаційних тенденцій в контексті результатів електорального циклу в країнах Латинської Америки і Карибського Басейну (ЛАКБ). Матеріали Х Міжнародної науково-практичної конференції «Соціалізація особистості у сучасних соціокультурних та соціо-політичних контекстах». Харківський національний педагогічний університет імені Г. С. Сковороди. Харків : ХНПУ, 2019. С. 47-52.

10. A World Awash in Change. George P. Shultz. URL: https:// www.hoover.org/sites/default/files/research/docs/george_shultz_ blueprint_for_america_aworldawashinchange.pdf.

11. Atkinson R.D., Lind M. National Developmentalism: From Forgotten Tradition to New Consensus / Robert D. Atkinson, Michael Lind. American Affairs. 2019 Volume III, №2 (Summer 2019): P. 165-191.

12. AMLO protesta como nuevo presidente de Me'xico; inicia la Cuarta Trancformasio'n. URL: htpps://noticieros.televisa.com/ultimas-noticias/amlo-presidente-mexico-protesta-como-nuevo-presidente-mexico-inicia-cuarta-transformasion/.

13. Платошкин H. Переворот в Боливии. URL: https:// www.youtube.com/watch?v=yxXMpfZx8-U.

14. Алекс Каллиникос: «Грета Тунберг не читала Маркса, но быстро этому учится» URL: https://www.colta.ru/articles/society/22696aleks-kallinikos-greta-tunberg-ne-chitala-marksa-no-bystro-etomuuchitsya.

15. World Inequality Report 2018 Executive Summary. URL: https:// wir2018.wid.world/files/download/wir2018-summary-english.pdf.

16. Измерение глобального неравенства. URL: https://commons.com. ua/uk/izmerenie-globalnogo-neravenstva/.

17. Рейтинг инновационных экономик - 2019: Южная Корея лидирует шесть лет. URL: https://theworldonly.org/rejting-innovatsionnyh-ekonomik-2019/.

Barabash $O$. The heterogeneity of political processes in Latin America and the Caribbean and the complexity of the "sustainable development" perspective

Summary. The paper addresses in part the problem of the possibility of "sustainable development" in the spirit of the provisions of the United Nations Special Program in Latin America and the Caribbean in the face of contemporary economic difficulties, challenges of socio-political nature, and in the presence of problems both local and global. An attempt was made to find out on what material basis and under what enabling factors and targeted actions the program objectives would be successful. Latin American 
and Caribbean (LACB) countries were found to have entered a phase of democratic recession after the period of gradual penetration and consolidation of some institutions of the democratic political regime and, first and foremost, in connection with the implementation of democratic electoral legislation, the proliferation of anti-institutional strategies political actors, renewal of street protests. (Venezuela, Bolivia, Partial and Sectoral - Chile, Peru, Colombia). Therefore, protecting the conquest of democracy in the region is seen in the context of the need to consolidate democracy globally and reduce the risks to its future existence. It is emphasized that against the background of the problems of the world economy development and the reorientation of political strategies at the national level, the content center of perspectives is shifting from binary: democracy - totalitarianism to a meaningful plane that is related to the factors of economic growth and social protection. The economic component of the modern world, including political processes, is one of the key ones. It is concluded that further developments both in the world and in the region, including the variation in solving the complex of social quality problems in terms of economic growth, will depend on the development paradigm to be determined in the next year or two in the United States. The importance of developing national development programs at the national level and the introduction of innovative technologies is emphasized.

Key words: Latin America and the Caribbean, democratic recession, sustainable development, political processes, social inequality, geopolitics. 